\title{
Trace element geochemistry of kerogens from the central Niger Delta
}

\author{
T. O. Jegede ${ }^{1} \cdot$ S. A. Adekola ${ }^{2} \cdot$ A. Akinlua ${ }^{1}$
}

Received: 20 November 2017 / Accepted: 24 February 2018 / Published online: 14 March 2018

(c) The Author(s) 2018

\begin{abstract}
Trace elements in kerogens isolated from shale samples obtained from oil wells in the central Niger Delta were determined using atomic absorption spectrometry, with the aim to determine the depositional environment and source of the organic matter. The results showed that the concentrations of the elements in the kerogens ranged from 1.50 to $6470.00 \mathrm{ppm}$ and 3.50 to $7946.00 \mathrm{ppm}$ for Wells X and Y, respectively. In both wells, Fe was the most abundant element, while cobalt had the least concentration. Nickel had an enhanced concentration over vanadium in Well X, while the reversed was the case in Well Y. The distribution patterns of the trace elements indicate that most of the kerogens from the two wells have similar origin. The geochemical ratios calculated from the concentrations of the trace elements revealed kerogens from Well X have terrestrial organic matter input, while kerogens from Well $\mathrm{Y}$ have both mixed marine/terrestrial organic matter and terrestrial inputs. The concentrations of the trace elements also revealed that the organic materials of samples from Well $\mathrm{X}$ were deposited under oxic conditions, while those from Well Y were deposited under oxic-suboxic conditions.
\end{abstract}

Keywords Kerogen $\cdot$ Trace element $\cdot$ Origin $\cdot$ Depositional environment $\cdot$ Central Niger Delta

\section{Introduction}

The distribution of trace elements in sedimentary organic matter or source rock has become an important subject in petroleum geochemistry and consequently in petroleum exploration (Filby 1994; Alberdi-Genolet and Tocco 1999; Akinlua et al. 2007; Galarraga et al. 2008; Akinlua et al. 2010). The abundance, distribution pattern, and ratio of trace elements in kerogens or source rocks have become indispensable tools in the evaluation of depositional environment, origin and thermal maturity of organic matter (Tribovillard et al. 2006; Galarraga et al. 2008; Akinlua et al. 2007, 2010). Trace elements are particularly useful as indicators of palaeoenvironmental condition of sediments because of differential geochemical behaviour at different oxidation states of the elements (Tribovillard et al. 2006). It has been proven over time that the source of organic matter has profound consequence on the abundance of trace elements in kerogens or

A. Akinlua

aakinlua@oauife.edu.ng; geochemresearch@yahoo.com

1 Fossil Fuels and Environmental Geochemistry, Department of Chemistry, Obafemi Awolowo University, Ile-Ife, Nigeria

2 Department of Geology, Obafemi Awolowo University, Ile-Ife, Nigeria source rocks or oils (Lewan 1984; Udo et al. 1992; Akinlua et al. 2007, 2010).

The concentrations of trace elements and their ratios such as cobalt/nickel $(\mathrm{Co} / \mathrm{Ni})$, molybdenum/nickel $(\mathrm{Mo} / \mathrm{Ni})$, vanadium/nickel $(\mathrm{V} / \mathrm{Ni})$ and $\mathrm{V} /(\mathrm{V}+\mathrm{Ni})$ have been found to be reliable geochemical tools to characterise sediments on the bases of their origin, palaeoredox condition during deposition and maturity (Barwise 1990; Filby 1994; AlberdiGenolet and Tocco 1999; Tribovillard et al. 2006; Akinlua et al. 2007, 2010). Therefore, in this study, we utilised trace element abundances and their ratios for the characterisation of kerogens from the central Niger Delta since it is cheaper to generate data on trace elements than the data on organic content of source rocks. Also there is paucity of data on trace element geochemistry of kerogens from central Niger Delta.

\section{Geological setting}

The Niger Delta sedimentary basin is one of the most prolific hydrocarbon province in the Africa. It is located in the Gulf of Guinea and covers an area of about $75,000 \mathrm{~km}^{2}$ (Haack et al. 2000), and consists of $12 \mathrm{~km}$ total thickness of regressive clastic sequences as discussed in the literature (Short and Stauble 1967; Avbovbo 1978; Doust and 


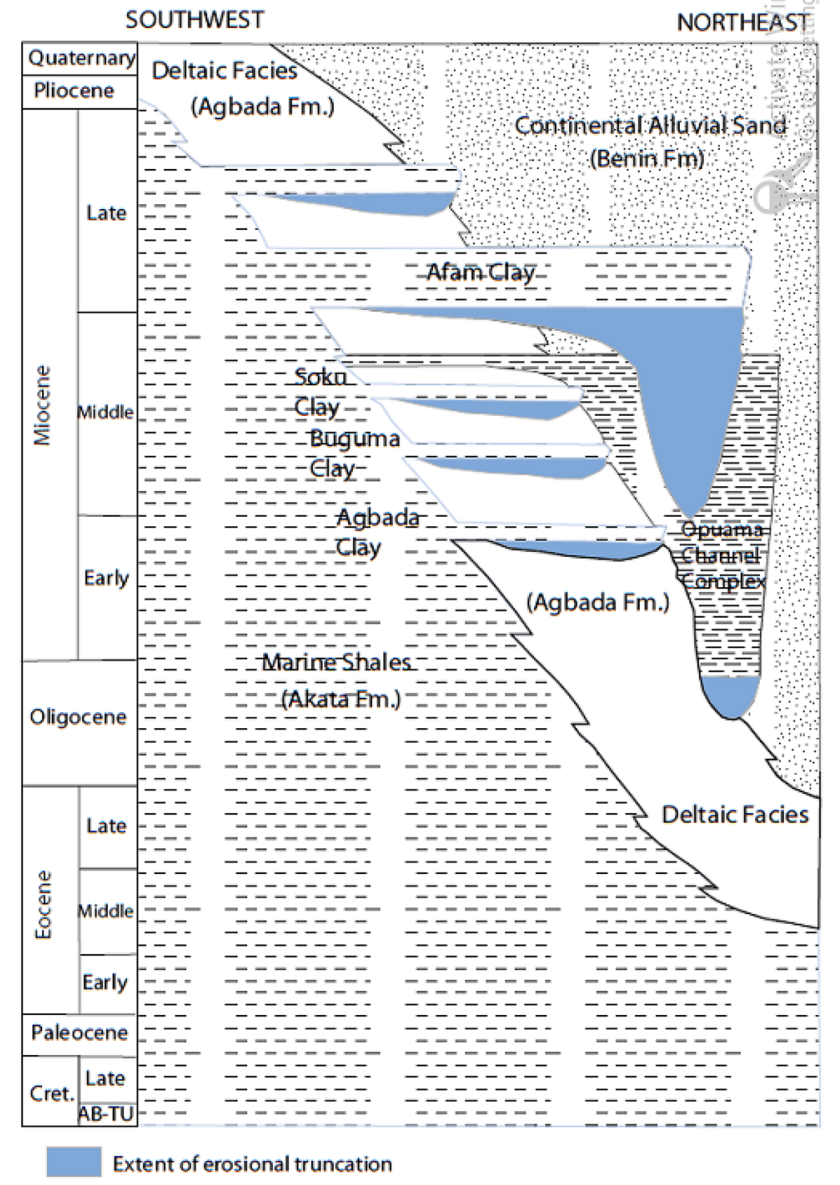

Fig. 1 Stratigraphic columns showing the three Formations of the Niger Delta Modified from Doust and Omatsola (1990)
Omatsola 1990; Kulke 1995). The Niger Delta evolution is related or linked with the formation of a rift triple junction during the separation of the South America and Africa plates in the Late Jurassic (Burke 1972; Whiteman 1992), that led to the opening of the Atlantic Ocean and gave rise to marine intrusion as evidenced by marine sedimentation in the Benue Trough and the Anambra Basin during the Cretaceous period (Doust and Omatsola 1990). On the basis of subsurface stratigraphy, the Tertiary Niger Delta is divided into three lithostratigraphic units (Fig. 1), which are Akata, Agbada and Benin Formations. The topmost Benin Formation is a continental deposit of alluvial and upper coastal plain sands with an age ranging from latest Eocene to Recent. The Agbada Formation, which consists of an intercalated sandstone and shale unit, underlies the Benin Formation. It is the major petroleum-bearing unit and began in the Eocene and continues into the Recent. The Akata Formation underlies the entire delta and is typically overpressured. The formation is essentially of deep marine origin and is composed of thick shale sequences with an age ranging from the Palaeocene to Recent (Avbovbo 1978).

\section{Experimental}

A total of forty-two shale samples, which were obtained from one of the oil companies through the Department of Petroleum Resources, comprising of twenty-three from Well $\mathrm{X}$ and nineteen from Well $\mathrm{Y}$ from the central Niger Delta were selected using a combination of geophysical well log and visual examination (Fig. 2). The rock samples were pre-extracted with dichloromethane (DCM) using Soxhlet
Fig. 2 Map of the Niger Delta showing location of the study area

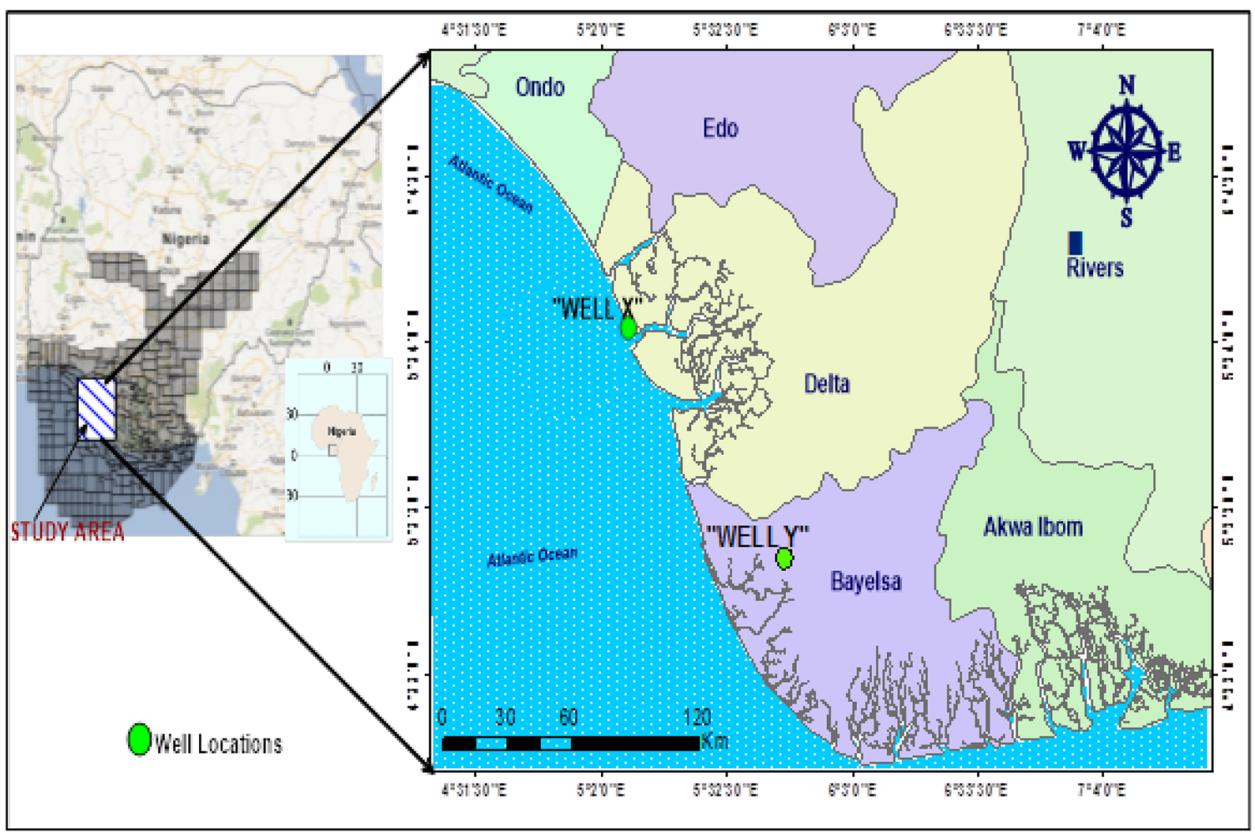


extraction for removal of soluble organic matter. Heating mantle with thermostat was used in order to control the heat during the Soxhlet extraction process. The process involves refluxing the rock samples with the solvent for $24 \mathrm{~h}$. Isolation of kerogen from the pre-extracted sample was effected by treatment with $\mathrm{HCl}$ for removal of carbonates, removal of carbonates was ensured until effervescence ceases and the silicates were destroyed by treatment with HF, and removal of silicates was ensured until the residual rock material is no longer coarse and concentrated $\mathrm{HNO}_{3}$ was added for the removal of pyrites. The isolated kerogens were digested into aqueous solution with a mixture of $\mathrm{H}_{2} \mathrm{O}_{2}$ and $\mathrm{HNO}_{3}$ to make them ammenable to atomic absorption spectrometric analysis. Trace elements in the aqueous solutions were determined by atomic absorption spectrometry (AAS) using PerkinElmer AAnalyst 200 spectrophotometer.

\section{Results and discussion}

\section{Distribution of trace elements in the kerogen samples}

The concentrations of the trace elements in kerogen samples from Well X ranged from 1.50 to $6470 \mathrm{ppm}$ (Table 1). Iron $(\mathrm{Fe})$ is most abundant element with an average concentration of $3045 \mathrm{ppm}$, followed by manganese (Mn) that has an average concentration of $120.02 \mathrm{ppm}$, while cobalt has the least concentration. Nickel (Ni) is the most abundant biophile element, with an average concentration of $63.52 \mathrm{ppm}$ (Table 1). The enrichment of nickel over vanadium in this well (Fig. 3) indicates that oxic conditions prevailed during sedimentation.

Trace elements concentrations of kerogen samples from Well Y ranged from 3.50 to $7946.00 \mathrm{ppm}$ with a mean value of $3317.78 \mathrm{ppm}$. In this well, iron $(\mathrm{Fe})$ is also the most abundant element with an average of 3317.78 ppm (Fig. 3), followed by manganese $(\mathrm{Mn})$ with concentration ranging from 55.5 to $243.0 \mathrm{ppm}$ with a mean value of $131.05 \mathrm{ppm}$, while Cobalt has the least concentration. Vanadium (V) is the most

Table 1 Trace elements composition (in ppm) of kerogens from Well $\mathrm{X}$ in the central Niger Delta

\begin{tabular}{|c|c|c|c|c|c|c|c|c|}
\hline Sample & Depth (m) & V & $\mathrm{Cr}$ & $\mathrm{Co}$ & $\mathrm{Ni}$ & $\mathrm{Mn}$ & $\mathrm{Fe}$ & $\mathrm{Cu}$ \\
\hline $\mathrm{X} 1$ & 1460 & $89.00 \pm 3.50$ & $13.40 \pm 1.30$ & $11.00 \pm 1.00$ & $61.00 \pm 2.50$ & $212.00 \pm 8.00$ & $6470.00 \pm 68.18$ & $59.50 \pm 4.50$ \\
\hline $\mathrm{X} 2$ & 1478 & $77.00 \pm 3.00$ & $7.71 \pm 0.70$ & $6.50 \pm 0.70$ & $57.00 \pm 2.15$ & $189.00 \pm 6.01$ & $3250.00 \pm 41.53$ & $46.50 \pm 3.55$ \\
\hline $\mathrm{X} 3$ & 1497 & $54.00 \pm 2.00$ & $16.50 \pm 1.50$ & $8.50 \pm 0.91$ & $39.50 \pm 1.50$ & $155.00 \pm 5.00$ & $3088.00 \pm 38.18$ & $14.00 \pm 1.50$ \\
\hline $\mathrm{X} 4$ & 1515 & $20.50 \pm 1.15$ & $15.50 \pm 1.50$ & $1.50 \pm 0.05$ & $16.00 \pm 0.50$ & $171.00 \pm 5.50$ & $3650.00 \pm 44.10$ & $24.50 \pm 0.55$ \\
\hline $\mathrm{X} 5$ & 1533 & $123.00 \pm 3.00$ & $11.71 \pm 1.05$ & $8.50 \pm 0.71$ & $168.00 \pm 5.16$ & $202.50 \pm 7.00$ & $2270.00 \pm 23.50$ & $32.00 \pm 2.33$ \\
\hline X6 & 1551 & $59.00 \pm 2.05$ & $9.50 \pm 0.95$ & $7.02 \pm 0.50$ & $67.00 \pm 2.68$ & $99.50 \pm 4.10$ & $2041.00 \pm 22.35$ & $52.50 \pm 2.10$ \\
\hline $\mathrm{X} 7$ & 1570 & $63.00 \pm 2.15$ & $14.40 \pm 1.14$ & $9.01 \pm 0.55$ & $44.50 \pm 1.50$ & $107.00 \pm 4.50$ & $2170.00 \pm 21.05$ & $33.00 \pm 3.00$ \\
\hline $\mathrm{X} 8$ & 1606 & $102.50 \pm 3.00$ & $8.05 \pm 0.85$ & $5.01 \pm 0.50$ & $71.00 \pm 3.00$ & $161.5 \pm 3.00$ & $2470.00 \pm 26.88$ & $15.00 \pm 1.15$ \\
\hline X9 & 1643 & $48.50 \pm 1.80$ & $7.50 \pm 0.00$ & $10.02 \pm 1.04$ & $33.50 \pm 1.05$ & $87.50 \pm 2.50$ & $3088.00 \pm 37.18$ & $24.50 \pm 1.75$ \\
\hline $\mathrm{X} 10$ & 1661 & $87.00 \pm 2.70$ & $21.05 \pm 1.73$ & $12.01 \pm 1.28$ & $93.00 \pm 3.15$ & $117.00 \pm 1.80$ & $1201.00 \pm 14.02$ & $7.00 \pm 0.12$ \\
\hline X11 & 1698 & $37.50 \pm 1.30$ & $11.50 \pm 1.05$ & $10.00 \pm 1.00$ & $56.00 \pm 2.00$ & $106.00 \pm 3.50$ & $2201.00 \pm 18.55$ & $13.50 \pm 1.05$ \\
\hline $\mathrm{X} 12$ & 1716 & $39.00 \pm 1.33$ & $6.50 \pm 0.05$ & $13.00 \pm 1.50$ & $49.50 \pm 3.00$ & $78.00 \pm 2.00$ & $4101.00 \pm 46.15$ & $15.01 \pm 2.00$ \\
\hline X13 & 1734 & $41.00 \pm 0.91$ & $13.50 \pm 1.35$ & $16.50 \pm 1.50$ & $155.00 \pm 5.15$ & $249.50 \pm 8.30$ & $2332.00 \pm 23.02$ & $28.50 \pm 2.08$ \\
\hline X14 & 1753 & $53.50 \pm 1.55$ & $17.05 \pm 1.70$ & $9.50 \pm 0.85$ & $74.00 \pm 2.45$ & $64.00 \pm 1.85$ & $6374.00 \pm 56.22$ & $16.50 \pm 1.40$ \\
\hline X15 & 1771 & $39.50 \pm 1.50$ & $6.50 \pm 0.05$ & $7.50 \pm 0.71$ & $68.00 \pm 2.00$ & $92.50 \pm 1.95$ & $2370.00 \pm 18.84$ & $23.50 \pm 1.35$ \\
\hline X16 & 1789 & $62.50 \pm 2.25$ & $8.15 \pm 0.85$ & $15.0 \pm 1.50$ & $70.00 \pm 3.00$ & $75.00 \pm 1.50$ & $4332.00 \pm 47.71$ & $25.00 \pm 2.00$ \\
\hline X17 & 1826 & $32.50 \pm 1.00$ & $12.50 \pm 0.98$ & $5.00 \pm 0.50$ & $21.50 \pm 1.10$ & $65.00 \pm 0.95$ & $3894.00 \pm 37.19$ & $44.00 \pm 2.88$ \\
\hline X18 & 1844 & $29.00 \pm 1.05$ & $9.55 \pm 0.65$ & $5.50 \pm 0.55$ & $47.00 \pm 1.35$ & $159.00 \pm 4.23$ & $2104.00 \pm 21.00$ & $22.00 \pm 1.82$ \\
\hline X19 & 1881 & $44.00 \pm 1.40$ & $5.50 \pm 0.01$ & $4.50 \pm 0.35$ & $51.50 \pm 1.50$ & $82.50 \pm 1.90$ & $3101.00 \pm 31.05$ & $5.50 \pm 0.51$ \\
\hline X20 & 1936 & $52.50 \pm 2.15$ & $17.00 \pm 1.50$ & $3.50 \pm 0.30$ & $63.50 \pm 2.03$ & $101.00 \pm 3.10$ & $2101.00 \pm 17.71$ & $5.00 \pm 0.00$ \\
\hline $\mathrm{X} 21$ & 1990 & $33.50 \pm 0.95$ & $6.10 \pm 0.05$ & $7.01 \pm 0.51$ & $66.00 \pm 2.50$ & $51.00 \pm 0.75$ & $3332.00 \pm 41.05$ & $18.00 \pm 2.00$ \\
\hline $\mathrm{X} 22$ & 2009 & $19.10 \pm 0.91$ & $9.20 \pm 0.95$ & $3.00 \pm 0.30$ & $21.50 \pm 1.05$ & $44.00 \pm 0.60$ & $2374.00 \pm 19.75$ & $16.00 \pm 1.22$ \\
\hline $\mathrm{X} 23$ & 2027 & $57.00 \pm 2.00$ & $11.05 \pm 1.05$ & $8.00 \pm 0.85$ & $67.00 \pm 2.50$ & $91.00 \pm 2.10$ & $1721.00 \pm 17.05$ & $12.50 \pm 1.12$ \\
\hline Average & & $54.96 \pm 26.09$ & $11.28 \pm 4.22$ & $8.13 \pm 3.76$ & $63.52 \pm 36.16$ & $120.02 \pm 56.24$ & $3045.00 \pm 1323.97$ & $24.07 \pm 14.78$ \\
\hline
\end{tabular}

$n=3$ 
Fig. 3 Relative distribution of trace elements in kerogens from the wells

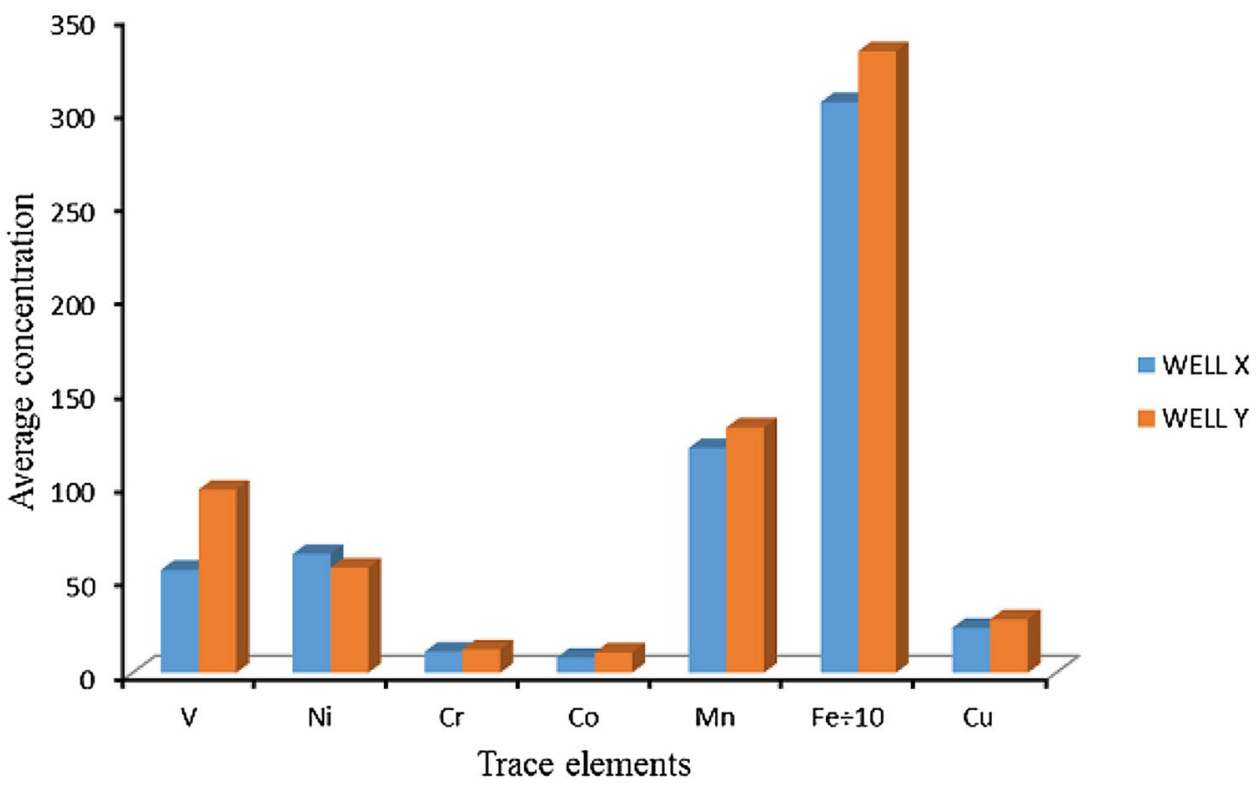

abundant biophile element, with a mean value of $97.82 \mathrm{ppm}$ (Table 2). The results in this well show an enhanced concentration of vanadium over that of nickel (Table 2), which suggests deposition of the organic matter in reducing environment (Lewan 1984).
The concentrations of elements in the two wells show no particular trend with depth. The trace elements distribution patterns of kerogens in the two wells (Figs. 4, 5) were used to evaluate their similarity or otherwise. Most of the samples from Well $\mathrm{X}$ have similar distribution patterns except some samples (Fig. 4). Kerogen samples from Well Y show similar trace elements distribution patterns (Fig. 5), indicating similar genetic origin.

Table 2 Trace elements composition (in ppm) of kerogens from Well Y in the central Niger Delta

\begin{tabular}{|c|c|c|c|c|c|c|c|c|}
\hline Sample & Depth (m) & V & $\mathrm{Cr}$ & Co & $\mathrm{Ni}$ & $\mathrm{Mn}$ & $\mathrm{Fe}$ & $\mathrm{Cu}$ \\
\hline Y1 & 2243 & $277.50 \pm 7.50$ & $33.50 \pm 1.90$ & $24.00 \pm 1.25$ & $114.00 \pm 4.98$ & $243.00 \pm 9.50$ & $5212.00 \pm 52.14$ & $56.50 \pm 3.50$ \\
\hline $\mathrm{Y} 2$ & 2353 & $134.50 \pm 5.65$ & $21.10 \pm 1.15$ & $19.00 \pm 0.95$ & $61.50 \pm 2.12$ & $179.00 \pm 6.95$ & $4489.50 \pm 44.44$ & $51.50 \pm 3.30$ \\
\hline Y3 & 2518 & $97.00 \pm 4.50$ & $17.55 \pm 1.05$ & $12.00 \pm 0.64$ & $49.00 \pm 1.71$ & $157.00 \pm 5.25$ & $3307.50 \pm 27.71$ & $44.50 \pm 3.20$ \\
\hline Y4 & 2573 & $135.00 \pm 5.65$ & $9.00 \pm 0.87$ & $17.00 \pm 0.89$ & $55.00 \pm 1.95$ & $175.50 \pm 6.75$ & $5682.00 \pm 54.36$ & $21.50 \pm 1.15$ \\
\hline Y5 & 2627 & $124.50 \pm 5.05$ & $11.45 \pm 0.92$ & $6.50 \pm 0.35$ & $45.00 \pm 1.50$ & $115.50 \pm 4.95$ & $7946.00 \pm 78.95$ & $19.00 \pm 0.98$ \\
\hline Y6 & 2682 & $166.00 \pm 5.82$ & $18.00 \pm 1.23$ & $15.00 \pm 0.79$ & $85.50 \pm 3.51$ & $193.00 \pm 8.15$ & $2522.00 \pm 15.10$ & $36.00 \pm 2.10$ \\
\hline Y7 & 2737 & $96.00 \pm 3.80$ & $15.05 \pm 1.15$ & $11.00 \pm 0.71$ & $67.50 \pm 2.35$ & $166.00 \pm 6.02$ & $1702.50 \pm 13.07$ & $43.50 \pm 2.25$ \\
\hline Y8 & 2957 & $110.00 \pm 4.15$ & $12.50 \pm 0.97$ & $13.50 \pm 0.75$ & $77.00 \pm 2.85$ & $132.00 \pm 4.42$ & $1532.50 \pm 12.97$ & $24.00 \pm 1.22$ \\
\hline Y9 & 3066 & $87.00 \pm 3.40$ & $6.65 \pm 0.65$ & $7.00 \pm 0.41$ & $40.50 \pm 1.13$ & $181.00 \pm 7.86$ & $1489.50 \pm 10.42$ & $15.50 \pm 0.85$ \\
\hline Y10 & 3121 & $63.00 \pm 2.35$ & $9.95 \pm 0.91$ & $8.50 \pm 0.62$ & $52.00 \pm 1.80$ & $89.00 \pm 4.10$ & $2015.00 \pm 17.05$ & $14.50 \pm 0.82$ \\
\hline Y11 & 3176 & $89.00 \pm 3.55$ & $6.00 \pm 0.55$ & $10.50 \pm 0.70$ & $66.50 \pm 2.30$ & $106.00 \pm 4.84$ & $2175.00 \pm 19.81$ & $12.50 \pm 0.76$ \\
\hline Y12 & 3505 & $54.00 \pm 1.92$ & $4.50 \pm 0.27$ & $6.00 \pm 0.30$ & $35.00 \pm 0.97$ & $97.00 \pm 4.78$ & $3682.00 \pm 32.26$ & $15.50 \pm 0.83$ \\
\hline Y13 & 3615 & $33.00 \pm 2.35$ & $8.75 \pm 0.77$ & $3.50 \pm 0.17$ & $39.00 \pm 1.05$ & $149.00 \pm 5.17$ & $2312.50 \pm 15.31$ & $13.50 \pm 0.79$ \\
\hline Y14 & 3670 & $36.50 \pm 1.25$ & $11.04 \pm 0.88$ & $4.00 \pm 0.23$ & $13.50 \pm 0.65$ & $124.50 \pm 5.04$ & $2372.00 \pm 17.02$ & $33.00 \pm 2.10$ \\
\hline Y15 & 3889 & $112.00 \pm 4.80$ & $7.55 \pm 0.71$ & $6.50 \pm 0.31$ & $55.50 \pm 1.95$ & $106.50 \pm 4.68$ & $3031.50 \pm 18.97$ & $16.50 \pm 1.05$ \\
\hline Y16 & 3944 & $51.00 \pm 1.85$ & $10.08 \pm 1.02$ & $9.00 \pm 0.68$ & $45.00 \pm 1.55$ & $62.50 \pm 3.11$ & $2625.00 \pm 17.60$ & $42.00 \pm 2.40$ \\
\hline Y17 & 4164 & $34.00 \pm 0.96$ & $7.07 \pm 0.65$ & $5.00 \pm 0.28$ & $38.00 \pm 1.01$ & $67.00 \pm 3.28$ & $4945.00 \pm 48.50$ & $11.00 \pm 0.90$ \\
\hline Y18 & 4218 & $102.00 \pm 3.58$ & $15.05 \pm 1.25$ & $21.00 \pm 1.13$ & $79.00 \pm 3.22$ & $91.00 \pm 4.14$ & $3702.50 \pm 37.17$ & $38.00 \pm 3.20$ \\
\hline Y19 & 4273 & $56.50 \pm 2.15$ & $12.85 \pm 1.02$ & $6.50 \pm 0.37$ & $48.50 \pm 1.65$ & $55.50 \pm 3.00$ & $2294.00 \pm 16.06$ & $33.50 \pm 2.20$ \\
\hline Average & & $97.82 \pm 57.74$ & $12.51 \pm 6.75$ & $10.82 \pm 5.99$ & $56.16 \pm 22.29$ & $131.05 \pm 50.51$ & $3317.78 \pm 1686.39$ & $28.53 \pm 14.5$ \\
\hline
\end{tabular}


Fig. 4 Trace elements distribution patterns of kerogens from Well X
Fig. 5 Trace elements distribution patterns of kerogens from Well Y
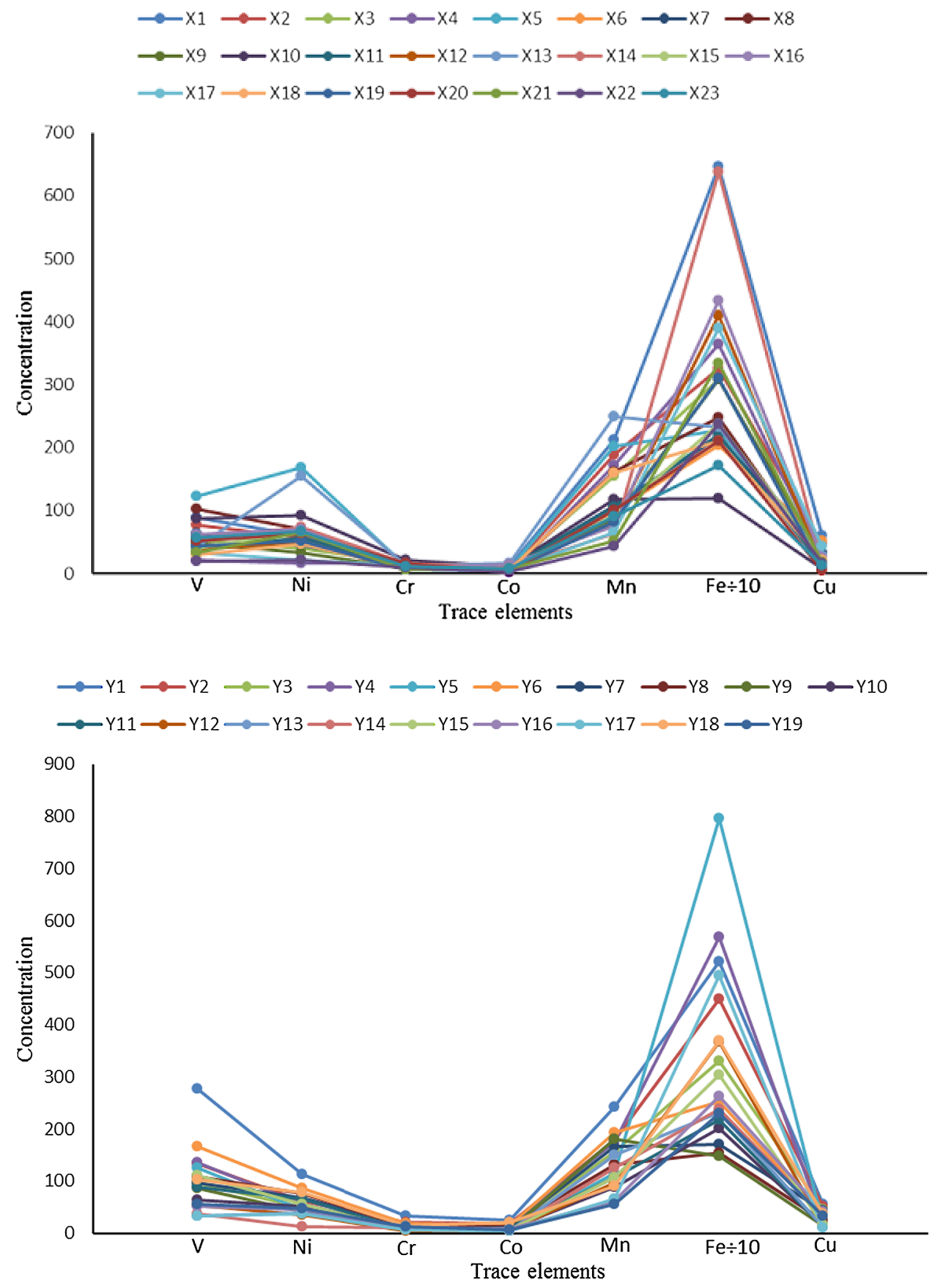

\section{Origin of the organic matter}

Previous studies have shown strong influence of origin of organic matter on the concentrations of trace elements in source rocks or oils especially those that have proven association with organic matter such as $\mathrm{V}, \mathrm{Ni}$ and $\mathrm{Co}$ (Lewan 1984; Barwise 1990; Udo et al. 1992; Akinlua et al. 2007). The geochemical ratios derived from such trace elements have proven to be invaluable tools in evaluating the organic matter input of source rocks. The values of $\mathrm{Co} / \mathrm{Ni}$ ratio for kerogen samples from the two wells are presented in Tables 3 and 4 . The Co/Ni ratios for Well $\mathrm{X}$ samples ranged from 0.05 to 0.30 (Table 4). About five samples $(\mathrm{X} 4, \mathrm{X} 5, \mathrm{X} 8, \mathrm{X} 19$ and $\mathrm{X} 20)$ have $\mathrm{Co} / \mathrm{Ni}$ ratios less than 0.1 suggesting terrestrial organic matter input, while the remaining samples have $\mathrm{Co} / \mathrm{Ni}$ ratios higher than 0.1 which suggests marine source input (Udo et al. 1992). The values of $\mathrm{Co} / \mathrm{Ni}$ ratio for kerogen samples from Well Y varied from 0.09 to 0.31 (Table 4), which suggests that most of the samples have marine organic matter input (Udo et al. 1992). An enhanced concentration of vanadium over that of nickel is an indication of marine organic 
Table 3 Geochemical parameters for kerogen samples from Well X

\begin{tabular}{llllrll}
\hline Sample ID & Depth $(\mathrm{m})$ & $\mathrm{Co} / \mathrm{Ni}$ & $\mathrm{V} / \mathrm{Ni}$ & \multicolumn{1}{c}{$\mathrm{Fe} / \mathrm{V}$} & $\mathrm{V} /(\mathrm{V}+\mathrm{Ni})$ & $\mathrm{TTE}(\mathrm{ppm})$ \\
\hline X1 & 1460 & 0.18 & 1.46 & 72.69 & 0.59 & 6915.90 \\
X2 & 1478 & 0.11 & 1.35 & 42.21 & 0.58 & 3633.71 \\
X3 & 1497 & 0.22 & 1.37 & 57.19 & 0.58 & 3375.50 \\
X4 & 1515 & 0.09 & 1.28 & 178.05 & 0.56 & 3899.00 \\
X5 & 1533 & 0.05 & 0.73 & 18.46 & 0.42 & 2815.71 \\
X6 & 1551 & 0.11 & 0.88 & 34.59 & 0.47 & 2335.52 \\
X7 & 1570 & 0.20 & 1.42 & 34.44 & 0.59 & 2440.91 \\
X8 & 1606 & 0.07 & 1.44 & 24.10 & 0.59 & 2833.06 \\
X9 & 1643 & 0.30 & 1.45 & 63.67 & 0.59 & 3299.52 \\
X10 & 1661 & 0.13 & 0.94 & 13.81 & 0.48 & 1538.06 \\
X11 & 1698 & 0.18 & 0.67 & 58.69 & 0.40 & 2435.50 \\
X12 & 1716 & 0.26 & 1.27 & 105.15 & 0.44 & 4302.00 \\
X13 & 1734 & 0.11 & 0.27 & 56.88 & 0.21 & 2836.00 \\
X14 & 1753 & 0.13 & 0.72 & 119.14 & 0.42 & 6608.55 \\
X15 & 1771 & 0.11 & 0.58 & 60.00 & 0.37 & 2607.50 \\
X16 & 1789 & 0.21 & 0.89 & 35.40 & 0.47 & 4587.65 \\
X17 & 1826 & 0.23 & 1.51 & 119.80 & 0.60 & 4074.50 \\
X18 & 1844 & 0.12 & 0.62 & 72.55 & 0.38 & 2376.05 \\
X19 & 1881 & 0.09 & 0.85 & 70.48 & 0.46 & 3294.50 \\
X20 & 1936 & 0.06 & 0.83 & 40.02 & 0.45 & 2343.50 \\
X21 & 1990 & 0.11 & 0.51 & 99.46 & 0.34 & 3513.61 \\
X22 & 2009 & 0.14 & 0.89 & 124.29 & 0.47 & 2486.80 \\
X23 & 2027 & 0.12 & 0.85 & 30.19 & 0.46 & 1967.55 \\
Average & & 0.15 & 0.99 & 66.58 & 0.48 & 3326.98 \\
\hline & & & & & &
\end{tabular}

TTE total trace elements
Table 4 Geochemical parameters for kerogen samples from Well Y

\begin{tabular}{lllllll}
\hline Sample ID & Depth $(\mathrm{m})$ & $\mathrm{Co} / \mathrm{Ni}$ & $\mathrm{V} / \mathrm{Ni}$ & $\mathrm{Fe} / \mathrm{V}$ & $\mathrm{V} /(\mathrm{V}+\mathrm{Ni})$ & $\mathrm{TTE}(\mathrm{ppm})$ \\
\hline Y1 & 2243 & 0.21 & 2.43 & 18.78 & 0.71 & 5960.50 \\
Y2 & 2353 & 0.31 & 2.19 & 33.38 & 0.69 & 4956.10 \\
Y3 & 2518 & 0.25 & 1.98 & 34.10 & 0.66 & 3684.55 \\
Y4 & 2573 & 0.31 & 2.46 & 42.00 & 0.71 & 6095.00 \\
Y5 & 2627 & 0.14 & 2.77 & 63.80 & 0.74 & 8267.95 \\
Y6 & 2682 & 0.18 & 1.94 & 15.19 & 0.66 & 3035.50 \\
Y7 & 2737 & 0.16 & 1.42 & 17.73 & 0.59 & 2101.55 \\
Y8 & 2957 & 0.18 & 1.43 & 13.93 & 0.59 & 1901.50 \\
Y9 & 3066 & 0.17 & 2.15 & 17.12 & 0.68 & 1827.15 \\
Y10 & 3121 & 0.16 & 1.21 & 31.98 & 0.55 & 2251.95 \\
Y11 & 3176 & 0.16 & 1.34 & 24.44 & 0.57 & 2465.50 \\
Y12 & 3505 & 0.17 & 1.54 & 68.19 & 0.61 & 3894.00 \\
Y13 & 3615 & 0.09 & 0.85 & 70.08 & 0.46 & 2559.25 \\
Y14 & 3670 & 0.29 & 2.70 & 64.99 & 0.73 & 2594.54 \\
Y15 & 3889 & 0.12 & 2.02 & 27.07 & 0.67 & 3336.05 \\
Y16 & 3944 & 0.20 & 1.13 & 51.47 & 0.53 & 2844.58 \\
Y17 & 4164 & 0.13 & 0.89 & 145.44 & 0.47 & 5107.07 \\
Y18 & 4218 & 0.27 & 1.29 & 36.30 & 0.56 & 4048.55 \\
Y19 & 4273 & 0.13 & 1.17 & 40.60 & 0.54 & 2507.35 \\
Average & & 0.19 & 1.73 & 42.98 & 0.62 & 3654.67 \\
\hline
\end{tabular}


matter input (Lewan 1984; Barwise 1990). It has also been reported that $\mathrm{V} / \mathrm{Ni}$ ratio with values greater than 3 indicate marine organic matter, values from 1.9 to 3 indicate mixed marine and values less than 1.9 indicate terrestrial organic matter input (Galarraga et al. 2008). The values of $\mathrm{V} / \mathrm{Ni}$ ratio for the kerogen samples from Well $\mathrm{X}$ ranged from 0.27 to 1.51 (Table 4), suggesting mainly terrestrial organic matter input. While the values of V/Ni ratio of Well Y kerogen samples ranged from 0.85 to 2.77, which suggests that source rock samples from Well $\mathrm{Y}$ contain organic matter that are of terrestrial and mixed marine/terrestrial origins. Samples from shallower depths are mainly of mixed organic matter input, while those from deeper depths are of terrestrial organic matter input.
The plot of V/Ni versus Co/Ni (Fig. 6) revealed that most of the samples from Well $\mathrm{Y}$ and all the samples from Well $\mathrm{X}$ are of terrestrial organic matter origin, while some kerogen samples (nine samples) from Well Y are of mixed marine/ terrestrial organic matter origin, which is indicative of Type III and Type II/III kerogens. Dendrogram cluster analysis of the kerogen samples (Fig. 7) using the geochemical ratios of the biophile elements as variables was carried out to determine their similarity or otherwise. Two groups are evident: kerogen samples of mixed marine/terrestrial organic matter origin (nine samples) form one group, while kerogen samples of terrestrial organic matter origin constitute another group. Cluster analysis classified the kerogen samples based on organic matter origin. A plot of vanadium against nickel
Fig. 6 Cross-plot of $\mathrm{Co} / \mathrm{Ni}$ versus $\mathrm{V} / \mathrm{Ni}$ indicating that kerogens from the central Niger Delta have both terrestrial and mixed marine/terrestrial origins. (Modified after Galarraga et al. 2008)

Fig. 7 Dendrogram cluster analysis of kerogen samples from the central Niger Delta using $\mathrm{Co} / \mathrm{Ni}, \mathrm{V} /(\mathrm{V}+\mathrm{Ni})$ and $\mathrm{V} /$ $\mathrm{Ni}$ as variables
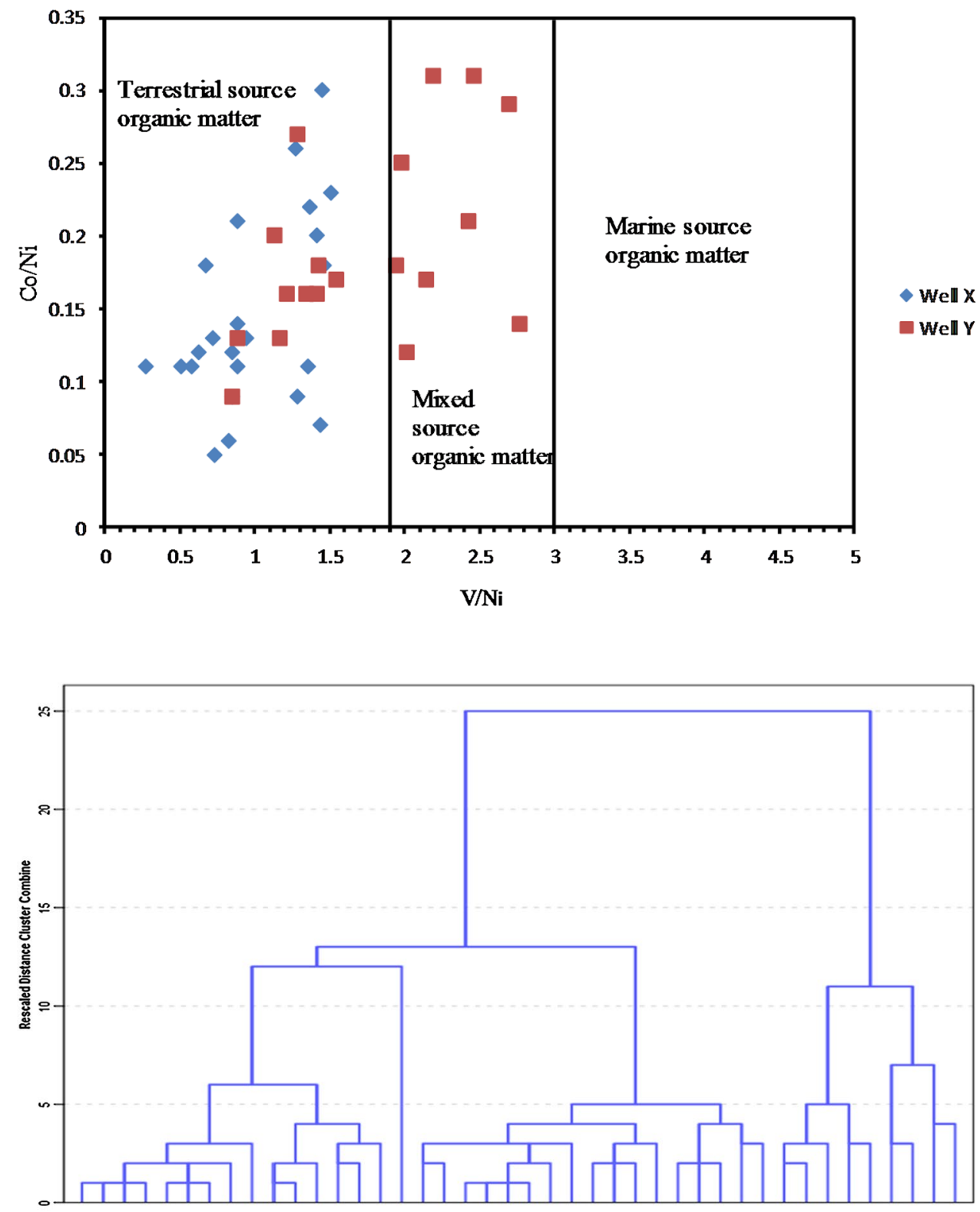

윯 
(Fig. 8) also indicates that most of the samples from the two wells have terrestrial organic matter origin, while some kerogen samples from Well Y have mixed marine/terrestrial origin, which is in agreement with the results of plot of $\mathrm{Co} /$ $\mathrm{Ni}$ versus $\mathrm{V} / \mathrm{Ni}$.

\section{Depositional environment of the organic matter}

As the origin of organic matter has profound effect on the concentrations of trace elements so also the depositional environment of the organic matter (Lewan 1984; Barwise 1990; Akinlua et al. 2007, 2010). A number of trace elements have been implicated as palaeoredox condition indicators, which include $\mathrm{V}, \mathrm{Ni}, \mathrm{Co}, \mathrm{Mo}, \mathrm{Mn}, \mathrm{Cu}$ and $\mathrm{Cr}$ (McManus et al. 1999; Morford et al. 2001; Algeo and Maynard 2004; Harris et al. 2004; Akinlua et al. 2010; MacDonald et al. 2010; Fu et al. 2011).

There is usually an enrichment of vanadium over nickel in anoxic marine environments (Barwise 1990; Peters and Moldowan 1993; Galarraga et al. 2008). Therefore, V/Ni ratio is a good indicator of anoxic or oxic environment of deposition. The distribution of the trace elements in kerogen samples from Well X (Table 2) shows an enhanced nickel concentration over the concentration of vanadium. The values of $\mathrm{V} / \mathrm{Ni}$ ratio of kerogen samples in Well $\mathrm{X}$ range from 0.27 to 1.51 (Table 3 ), which indicate that the organic matter of most of the samples was deposited under oxic conditions except those in shallow depths (Fig. 8). The distribution of trace elements in kerogen samples from Well Y (Table 4) shows an enhanced concentration of vanadium over nickel except for samples Y13 and Y17. The values of V/Ni ratio for these samples range from 0.85 to 2.77 (Table 4) which indicates that the organic materials of the samples were deposited under anoxic conditions. $\mathrm{V} /(\mathrm{V}+\mathrm{Ni})$ ratio is also a good indicator of depositional environment, high value is an indication of reducing anoxic conditions, while low value indicates oxic to dysoxic conditions (Lewan 1984; Moldowan et al. 1985; Barwise 1990). The values of V/ $(\mathrm{V}+\mathrm{Ni})$ ratio for Well $\mathrm{X}$ kerogen samples ranged from 0.21 to 0.60 , indicating deposition of organic matter under oxic conditions. Well Y kerogen samples have $\mathrm{V} /(\mathrm{V}+\mathrm{Ni})$ values that ranged from 0.47 to 0.74 (Table 4 ), which indicate that the organic matter of most of the samples was deposited under anoxic conditions, while samples Y13 and Y17 indicate deposition under dysoxic-oxic conditions.

Iron is greatly enriched relative to other elements in all the samples studied with values ranging from 1201.00 to $6470.00 \mathrm{ppm}$ for Well $\mathrm{X}$ (Table 2) and 1532.50 to 7946.00 ppm for Well Y (Table 3). This indicates that the organic matter received high Fe oxyhydroxides input due to strong terrestrial influences, and these oxyhydroxides were well preserved under varying oxic and suboxic conditions (Byrne and Kester 1976; Froelich et al. 1979; Burdige 1993; Liu and Millero 2003). The enrichment of Mn over all the other elements (except Fe) in all the samples is a further indication of the oxic and suboxic environments in which the organic materials were deposited (Froelich et al. 1979; Lovley 1991; Burdige 1993; Morford and Emerson 1999).

Chromium is soluble in oxidising conditions and sparingly soluble in reducing conditions (Algeo and Maynard 2004). The concentration of $\mathrm{Cr}$ is generally low (only higher than $\mathrm{Co}$ ) in all the samples with values ranging from 4.50 to $33.50 \mathrm{ppm}$, which suggests oxic-suboxic depositional conditions for the organic materials. Similarly, $\mathrm{Cu}$ is a
Fig. 8 Cross-plot of vanadium versus nickel showing that kerogens from the central Niger Delta have terrestrial and mixed marine/terrestrial source inputs and were deposited under varying oxic to dysoxic conditions (Modified after Galarraga et al. 2008)

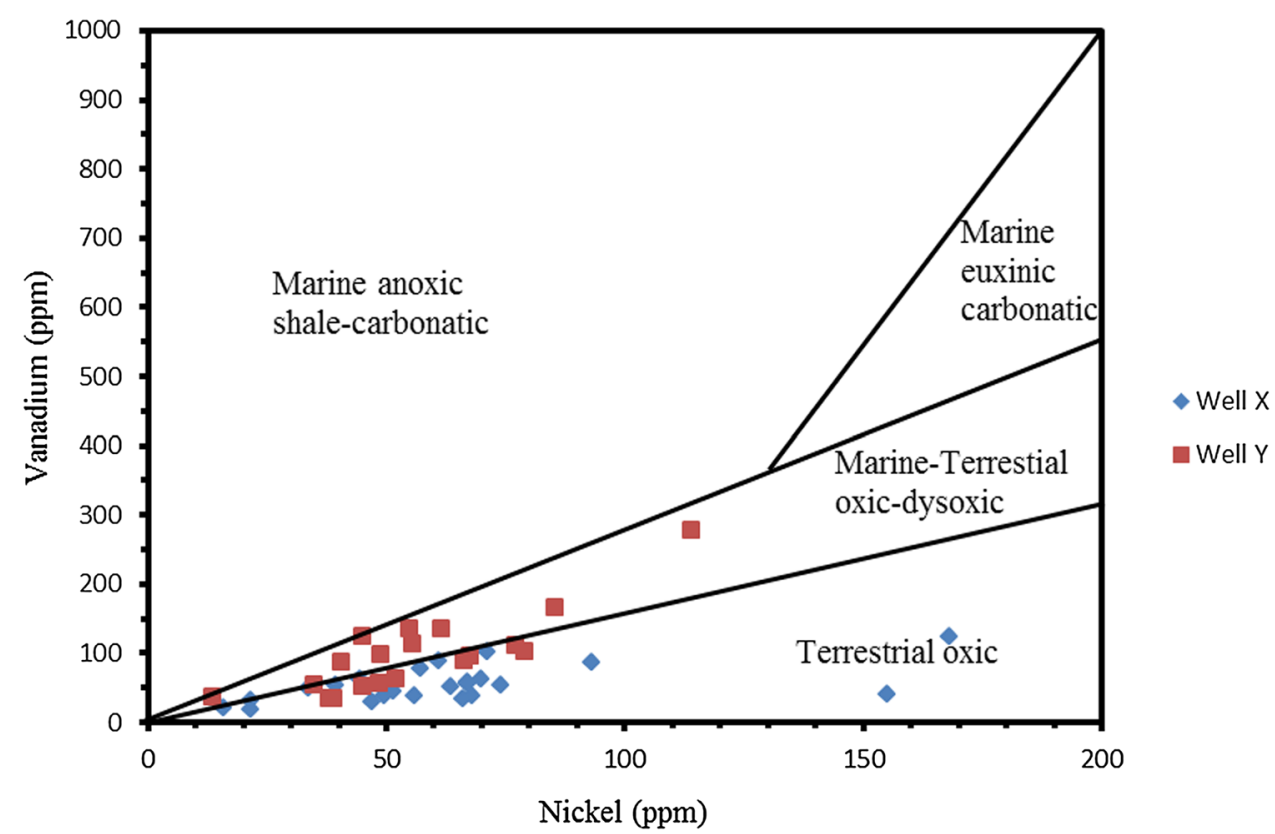


redox-sensitive element which is usually enriched in anoxic conditions (Tribovillard et al. 2006). Cu is slightly enriched with average concentrations of 24.10 and $28.53 \mathrm{ppm}$ in Wells $\mathrm{X}$ and $\mathrm{Y}$, respectively, which could also be an indication of oxic-suboxic conditions.

\section{Conclusions}

The distribution of trace elements in kerogens of shale samples from two oil wells in the central Niger Delta revealed that there is prevalence of terrestrial organic matter with subordinate mixed marine/terrestrial organic matter. The organic materials were deposited under conditions ranging from oxic to suboxic.

Acknowledgements We are grateful to the Department of Petroleum Resources (DPR) for releasing the samples for this study. We are also grateful to Mr. T. A. Adesiyan for his assistance during sample preparation.

Open Access This article is distributed under the terms of the Creative Commons Attribution 4.0 International License (http://creativeco mmons.org/licenses/by/4.0/), which permits unrestricted use, distribution, and reproduction in any medium, provided you give appropriate credit to the original author(s) and the source, provide a link to the Creative Commons license, and indicate if changes were made.

\section{References}

Akinlua A, Torto N, Ajayi TR, Oyekunle JAO (2007) Trace metal characterisation of Niger Delta kerogens. Fuel 86:1358-1364

Akinlua A, Adekola SA, Swakamisa O, Fadipe OA, Akinyemi SA (2010) Trace element characterisation of Cretaceous Orange Basin hydrocarbon source rocks. Appl Geochem 25:1587-1595

Alberdi-Genolet M, Tocco R (1999) Trace metals and organic geochemistry of the Machiques Member (Aptian-Albian) and La Luna Formation (Cenomanian Campanian), Venezuela. Chem Geol 160:19-38

Algeo TJ, Maynard JB (2004) Trace-element behaviour and redox facies in core shales of Upper Pennsylvanian Kansas-type cyclothems. Chem Geol 206:289-318

Avbovbo AA (1978) Tertiary lithostratigraphy of the Niger Delta. AAPG Bull 62:295-306

Barwise AJG (1990) Role of nickel and vanadium in petroleum classification. Energy Fuels 4:647-652

Burdige DJ (1993) The biogeochemistry of manganese and iron reduction in marine sediments. Earth Sci Rev 35:249-284

Burke K (1972) Longshore drift, submarine canyons, and submarine fans in development of Niger Delta. AAPG Bull 56:1975-1983

Byrne RH, Kester DR (1976) Solubility of hydrous ferric oxide and iron speciation in sea water. Mar Chem 4:255-274

Doust H, Omatsola E (1990) Niger Delta. In: Edwards JD, Santogrossi PA (eds) Divergent/passive margin basins, 48. AAPG Memoir, Tulsa, pp 201-238

Filby R (1994) Origin and nature of trace element species in crude oil, bitumens and kerogen: implications for correlation and other geochemical studies. In: Parnell J (ed) Geofluids: origin, migration and evolution of fluids in sedimentary basins, vol 78 . Geological Society Special Publication, London, pp 203-219
Froelich PN, Klinkhammer GP, Bender ML, Luetge NA, Heath GR, Cullen D, Dauphin P (1979) Early oxidation of organic matter in pelagic sediments of the eastern equatorial Atlantic: suboxic diagenesis. Geochim Cosmochim Acta 43:1075-1090

Fu X, Wang J, Zeng Y, Cheng J, Tano F (2011) Origin and mode of occurrence of trace elements in marine oil shale from the Shengli River Area, Northern Tibet, China. Oil Shale 28:487-506

Galarraga F, Llamas JF, Martinez A, Martinez M, Marquez G (2008) Reategui K. V/Ni ratio as a parameter in palaeoenvironmental characterization of non-mature medium-crude oils from several Latin American basins. J Petrol Sci Eng 61:9-14

Haack RC, Sundararaman P, Diedjomahor JO, Xiao H, Gant NJ, May ED, Kelsch K (2000) Niger Delta petroleum systems Nigeria. In: Mello MR, Katz BJ (eds) Petroleum Systems of the South Atlantic Margins, 73. AAPG Memoir, Tulsa, pp 213-231

Harris NB, Freeman KH, Pancost RD, White TS, Mitchell GD (2004) The character and origin of lacustrine source rocks in the Lower Cretaceous synrift section, Congo Basin, West Africa. AAPG Bull $88: 1163-1184$

Kulke H (1995) Nigeria. In: Kulke H (ed) Regional petroleum geology of the world part II: Africa, America, Australia and Antarctica. Gebruder Borntraeger, Berlin, pp 143-172

Lewan MD (1984) Factors controlling the proportionality of vanadium to nickel in crude oils. Geochim Cosmochim Acta 48:2231-2238

Liu X, Millero FJ (2003) The solubility of iron in seawater. Mar Chem $77: 43-54$

Lovley D (1991) Dissimilatory Fe(III) and Mn(IV) reduction. Microbiol Rev 55:259-287

MacDonald R, Hardman D, Sprague R, Meridji Y, Mudjiono W, Galford J, Rourke M, Dix M, Kelto M (2010) Using elemental geochemistry to improve sandstone reservoir characterization: a case study from the Unayzah A interval of Saudi Arabia. In: SPWLA 51st Annual Logging Symposium, June 19-23, pp 1-16

McManus J, Berelson WM, Hammond DE, Klinkhammer GP (1999) Barium cycling in the North Pacific: implication for the utility of $\mathrm{Ba}$ as a paleoproductivity and paleoalkalinity proxy. Paleoceanography 14:62-73

Moldowan JM, Seifert WK, Gallegos EJ (1985) Relationship between petroleum composition and depositional environment of petroleum source rocks. AAPG Bull 69:1255-1268

Morford JL, Emerson SE (1999) The geochemistry of redox sensitive trace metals in sediments. Geochim Cosmochim Acta 63:1735-1750

Morford JL, Russell AD, Emerson S (2001) Trace metal evidence for changes in the redox environment associated with the transition from terrigenous clay to diatomaceous sediment, Saanich Inlet, BC. Mar Geol 174:355-369

Peters KE, Moldowan JM (1993) The biomarker guide: interpreting molecular fossils in petroleum and ancient sediments. PrenticeHall Inc, Englewood Cliffs

Short KC, Stauble AJ (1967) Outline of geology of Niger Delta. AAPG Bull. 51:761-779

Tribovillard N, Algeo TJ, Lyons T, Riboulleau A (2006) Trace metals as paleoredox and paleoproductivity proxies: an update. Chem Geol 232:12-32

Udo OT, Ekwere S, Abrakasa S (1992) Some trace metals in selected Niger Delta crude oils: application in oil-oil correlation studies. J Min Geol 28:289-291

Whiteman AJ (1992) Nigeria: its petroleum geology, resources and potential. Graham and Trotman, London

Publisher's Note Springer Nature remains neutral with regard to jurisdictional claims in published maps and institutional affiliations.

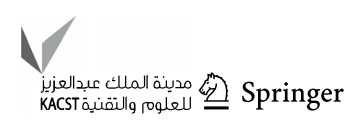

